() О. І. Хмілярчук, канд. техн. наук, доц., К. О. Чепурна, канд. техн. наук, доц., М. О. Клішина, магістр, КПІ ім. Ігоря Сікорського, Київ, Україна

\title{
ОЦІНКА ЯКОСТІ ВИГОТОВЛЕННЯ РОЗ'ЄМНИХ КОНСТРУКЦІЙ ПАПЕРОВО-БІЛОВОї ПРОДУКЦІї
}

\section{У статті представлено результати досліджень комплексного показника якості роз'ємних конструкцій паперово-білової продукції; досліджено вплив факторів на якість виготов- лення даного виду продукції методом експертних оцінок та розроблено діаграму Ісікави; сформовано алгоритм керування якості виготовлення роз'ємних конструкцій паперово-білової продукції.}

Ключові слова: оцінка якості; конструкція паперово-білової продукції; змінні елементи видань; вид скріплення зошитів; роз'ємні видання; післядрукарські операції; технологічні особливості виготовлення.

\section{Постановка проблеми}

Виготовлення роз'ємних конструкцій паперово-білової продукції довгий час було поширеним тільки в певних типорозмірах та стандартизованому виконанню. Проте за останнє десятиліття набули суттєвого поширення конструкції зі з'ємними та замінними елементами блоку $[1,2]$. Завдяки виникненню нових матеріалів та технологій з'являється можливість створення сучасних типів конструкцій видавничої та невидавничої, паперово-білової продукції, які неможливо було уявити раніше. Тож, оскільки ринок сировини постійно розвивається, поповнюючись новими видами матеріалів з новими властивостями, проблема забезпечення якості виготовлення продукції з неї залишається актуальним питанням.

Компанії, щоб виділитись серед конкурентів та вразити споживача високою якістю продукції, все частіше застосовують для її виготовлення нестандартні конструкції, нестандартні матеріали, велика частка яких має не лише особливі оптичні характеристики, а й фактуру. За результатами проведених раніше досліджень встановлено, що на відміну від звичайних, фактурні матеріали мають особливу текстуру, що надає нестандартні візуальні й тактильні відчуття. Серед фактурних матеріалів, що задовольняють потреби поліграфічної галузі, виділяють [3]: матеріали на основі 
целюлози (деякі види дизайнерського паперу та картону з високим коефіцієнтом шорсткості з включеннями бавовни, деревини тощо; папір або картон з попередньо сформованою поверхнею тисненням; деревина); матеріали шкірообробної промисловості (натуральна шкіра, замша); штучні матеріали (замінник шкіри, деякі палітурні матеріали); тканина (зокрема палітурні матеріали на тканинній основі).

Продукція оригінальної конструкції, що виготовлена з ексклюзивних матеріалів стає виразною та отримує особливий стиль.

\section{Аналіз попередніх досліджень}

За результатами попередніх досліджень [1] було виділено найпопулярніші та оригінальні нові конструкції видань зі змінними елементами блоку, а саме: видання зі скріпленням на кільця, на металеві тримачі, на резинки, за допомогою пластикового диску, видання з магнітним корінцем, видання зі стрижнем, зі скріпкошиною, з системою застібок оригамі. Також проаналізовано, систематизовано та розроблено класифікацію роз'ємних конструкцій паперово-білової продукції та наведено аналіз переваг та недоліків даних конструкцій [4]. Аналіз $[5,6]$ показав, що для даного виду продукції не встановлено систему оцінювання якості, аналіз [7-11] надає або загальні рекомендації, або ж присвячений системам оцінки якості виготовлення видавничої (книжкової та журнальної продукції). Особливо багато уваги присвячено системам оцінки якості продукції для дітей. Виготовлення роз'єм- них конструкцій паперово-білової продукції має особливості, відповідно, потребує розробки своєрідної методики оцінки якості виготовлення.

\section{Мета роботи}

Аналіз основних показників якості виготовлення роз'ємних конструкцій паперово-білової продукції, методів оцінки якості; встановлення причин виникнення браку, знаходження способів їх усунення; розробка методики оцінки якості виготовлення роз'ємних конструкцій паперово-білової продукції.

\section{Результати проведених досліджень}

За результатами виконання аналізу переваг та недоліків роз'ємних конструкцій паперовобілової продукції було визначено фактори, що впливають на якість виготовлення роз'ємних конструкцій паперово-білової продукції.

Під фактором виробництва паперово-білової продукції мається на увазі економічні ресурси, що необхідні для виготовлення виробів. До складових фактору виготовлення належать також матеріали для виготовлення, обладнання, людські ресурси (праця робочих на підприємстві) та фінансова складова.

При розгляданні матеріалів як складової фактору виготовлення, було визначено, що на довготривалість виготовлення впливає тип конструкції, складність конструкції (кількість деталей, складність скріплень), час ручних та машинних операцій при брошурувально-палітурних процесах.

Аналіз факторів, що впливають на якість виготовлення роз'ємних 
конструкцій паперово-білової продукції наведено на рис. 1. Серед факторів, що впливають на якість виготовлення роз'ємних конструкцій паперово-білової продукції виділено наступні.

І. Виготовлення блоку, зошитів, сторінок:

1. Колірні характеристики (яскравість, насиченість).

2. Градаційні характеристики (оптична густина).

3. Механічні та оптичні властивості паперу (маса, товщина, гладкість, пухкість, білизна, вологість).

II. Обладнання:

1. Додрукарське устаткування (калібрування, кольороподіл).

2. Друкарське обладнання (оптимальність параметрів друкування, подача матеріалів та фарби, технологія виготовлення).

3. Післядрукарська обробка (обрізування, перфорація, встановлення механізму скріплення, з'єднання блоку з палітуркою).

III. Матеріали:

1. Матеріал для скріплення блоку та палітурки паперово-білових виробів, а саме метал, пластик та дерево (фізико-хімічні властивості: маса, колір, товщина, прозорість, термічні властивості, міцність).

2. Друкарська фарба (відповідність параметрам друкарської фарби встановленим нормам).

3. Матеріал для блоку, що задруковується частково чи повністю.

4. Деталі механізмів скріплення паперово-білової продукції.

IV. Технологія:

1. Додрукарська обробка.

2. Технологія цифрового способу друку.
3. Технологія виготовлення папок та палітурок.

4. Технологія приєднання блоку з палітуркою на спеціальний механізм.

V. Методи та засоби вимірювання:

1. Засоби вимірювання (візуальний метод, денситометр, спектрофотометр, колориметр).

2. Контрольовані величини (градаційна передача (розтискування, оптична густина), тоно-, кольоропередача (колірне відхилення).

3. Навколишнє середовище.

VI. Персонал (економічна зацікавленість, умови праці, кваліфікація та спеціалізація, дисципліна).

Проаналізувавши вплив людських ресурсів, розглянуто ранжування факторів ризику. У процесі якісного аналізу факторів виготовлення роз'ємних видань визначено фактор ризику, при якому на виробництві не всі елементи відтворюються на одному підприємстві, наприклад, це специфічна форма $з$ металу чи дерева. Такі деталі можливо окремо замовити у фірм, що цим займаються. Так виникає необхідність виготовлення на аутсорсі, тобто має бути впевненість у виробі, що поставляється, його якість та відповідність термінам доставки. Завершено процес якісного аналізу фактору ризику віднесенням до категорії відомих ризиків, тобто це можливість невиконання до визначеного терміну. При ході виробництва також виникають передбачувані та непередбачувані ризики. Також розглянуто фактори виготовлення, які впливають на якість конструкцій паперово-білової продукції зі змінними блоками. 


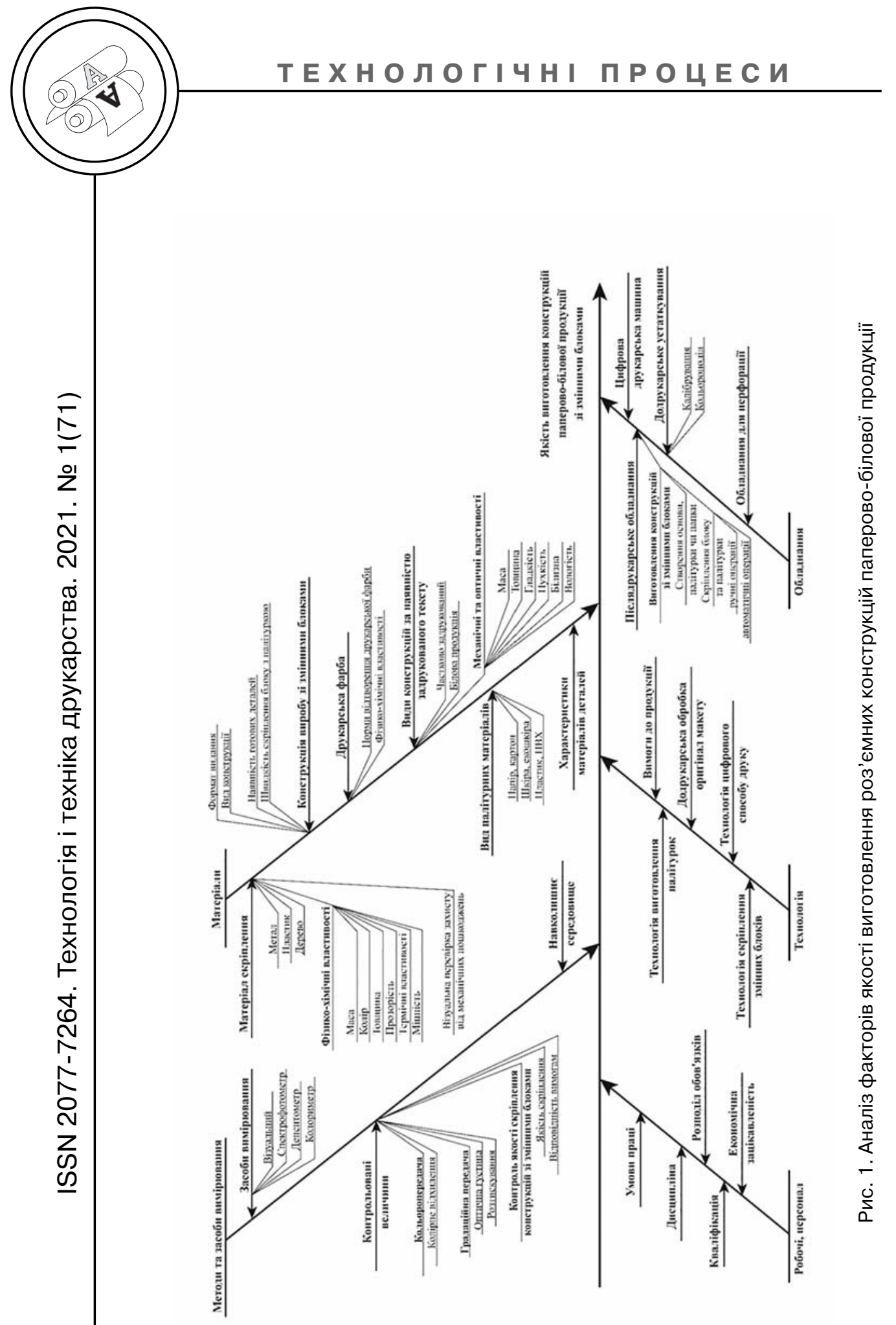


Комплексний показник якості видань з роз'ємними блоками це характеристика, визначена у кількості декількох факторів властивостей, які визначають якість продукції. Цей показник визначається відповідно до експлуатації та способів виготовлення.

При визначенні комплексного показника якості виготовлення роз'ємних конструкцій паперово-білової продукції перш за все визначено комплексні ознаки, а саме: призначення, надійність та довговічність, технологічність, естетичність та ергономічність, методи стандартизації та уніфікації, патентно-правовий захист, економічні показники та показники безпеки.

При дослідженні технологічних особливостей виготовлення видань з роз'ємним блоком, насамперед, необхідно було визначити методику виконання досліджень, виконати дослідження параметрів, які впливають на трудомісткість виготовлення видань з роз'ємним блоком.

Перед виконанням досліджень було проаналізовано технології виготовлення видань з роз'ємним блоком [1], їх використання, попит серед цільової аудиторії. Відповідно, в рамках виконання досліджень, було проведено опитування серед експертів, які надали оцінки матеріалів палітурок та папок, порівняння оцінки видань з роз'ємним блоком користувача та виробника сформовано у ієрархічній структурній схемі на рис. 2.

При використанні виробів паперово-білової продукції, а саме роз'ємних конструкцій, користувачі перш за все розглядають їх у контексті використання, на- самперед це визначає чи доцільним $€$ їх експлуатація в тій чи іншій ситуації.

Погляди користувача та виробника деколи відрізняються. Це спричинено тим, що при виробництві негативним при оцінці виробу до уваги береться технологія її виготовлення. Тобто, в певних випадках використання того чи іншого матеріалу може бути недоцільним або неможливим.

Після проведення опитування щодо зручності матеріалів палітурок та папок видань зі змінними блоками серед користувачів та їх виробників, було надано бальну оцінку кожному виду скріплення та їх матеріалу палітурки від 0 до 10 балів (рис. 2), де 0 це повністю невідповідність вимогам користувачів (стійкість до механічного пошкодження, міцність, довговічність, зручність користування, естетика, якість) та недоцільність користування; у виробників, 10 - максимальна оцінка, яка задовольняє параметрам якості, зручності, довговічності.

Для наочності експертних оцінок створено ієрархічну структурну схему експертних оцінок матеріалів палітурок та папок, оцінку видань з роз'ємним блоком користувача та виробника.

За результатами проведених досліджень розроблено алгоритм керування якості виготовлення роз'ємних конструкцій паперовобілової продукції, чим сформульовано вимоги до продукції та потреби або очікування користувачів. Якістю визначається ступінь, до якого сукупність характеристик задовольняє вимоги, що призводять до задоволення замовника та його сприйняття ступеня виконання вимог. 
При оцінці рівня якості продукції насамперед обрано номенклатуру показників якості та базові показники якості. Номенклатура показників якості продукції встановлює перелік кількісних характеристик її властивостей, що визначають якість. Враховано призначення і умови використання продукції, склад і структуру характеризованих вла- стивостей, вимоги споживачів до якості (результатів вивчення попиту) та основні вимоги до показників якості.

Також обрано способи та визначення значень показників якості, методи оцінювання рівня якості та обґрунтовано рекомендації з покращення властивостей продукції. Результати розробки алгоритму наведено на рис. 3.

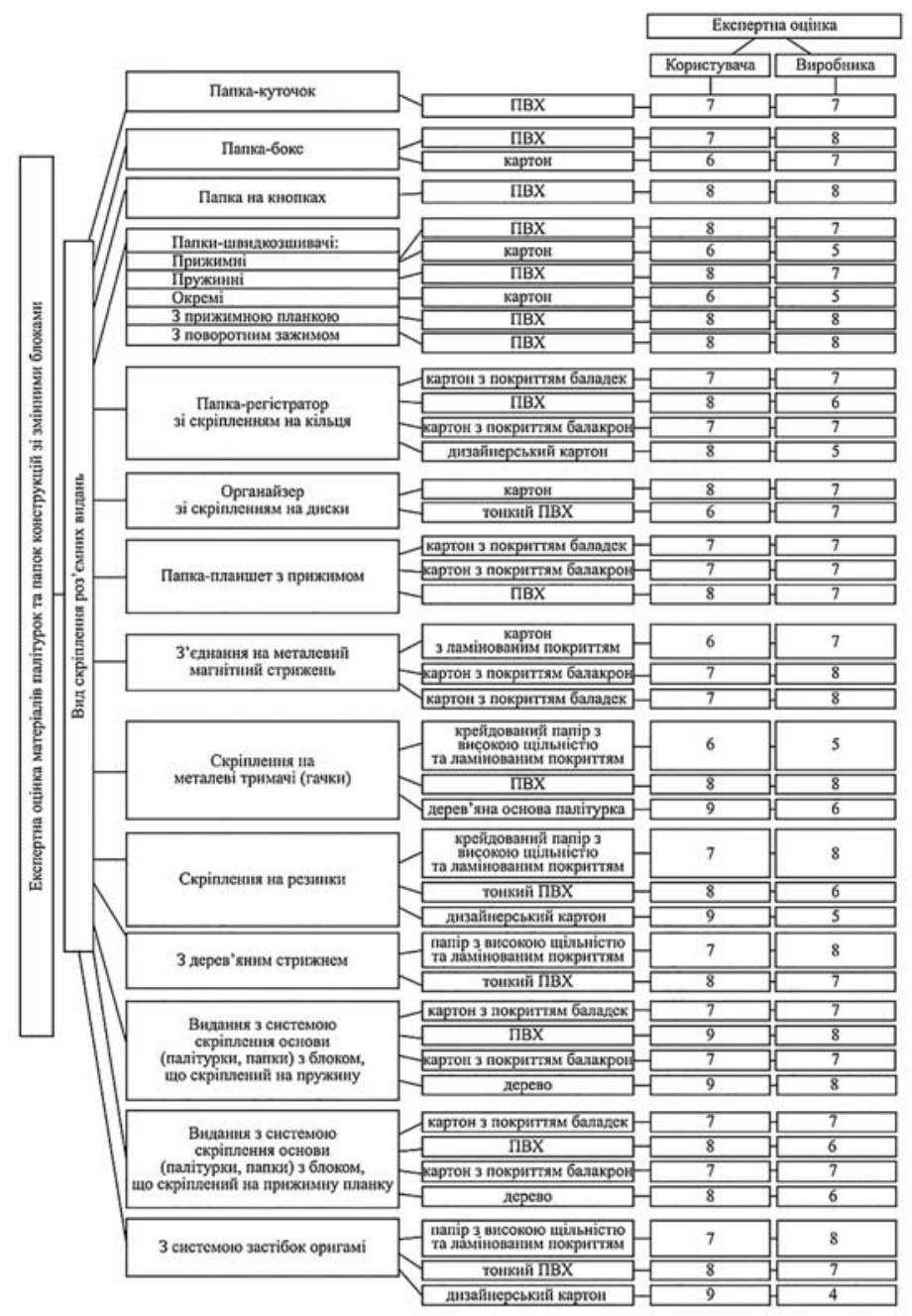

Рис. 2. Ієрархічна структурна схема експертних оцінок матеріалів роз'ємних конструкцій паперово-білової продукції 


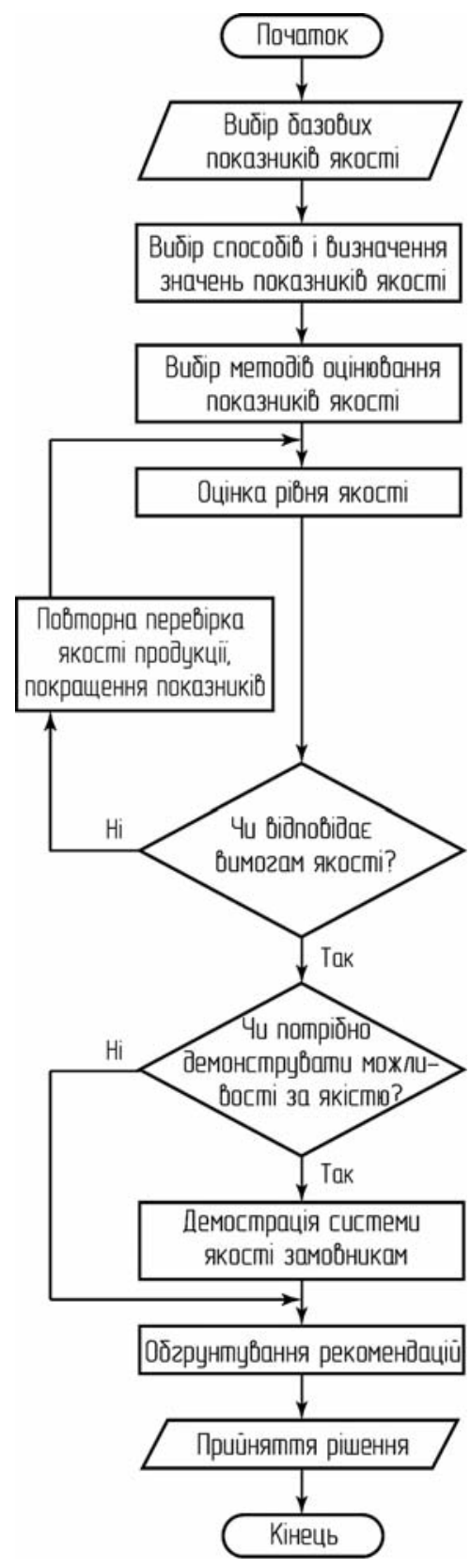

Рис. 3. Алгоритм комплексного показника якості виготовлення роз'ємних конструкцій паперово-білової продукції 


\section{Висновки}

В результаті виконаних досліджень проведено аналіз факторів впливу на якість роз'ємних конструкцій паперово-білової продукції, їх ранжування; представлено комплексний показник якості даного виду продукції, розроблено діаграму Ісікави.

Згідно із розробленою причинно-наслідковою діаграмою, систематизовано чинники впливу на якість виготовлення роз'ємних конструкцій паперово-білової продукції. Представлена діаграма дозволяє встановити можливі причини отримання браку на всіх етапах виготовлення продукції, провести аналіз причин появи браку та знайти шляхи їх усунення, що в цілому дозволить покращити якість. За результатами опитування двох експертних груп з користувачів (група 1) та виробників (група 2) продукції встановлено, що дані не завжди корелюються між собою. Відповідно продукція, що цікава споживачам, досить часто викликає складнощі в технологічних процесах виготовлення на виробництві.

За результатами аналізу окремих якісних показників паперово-білової продукції, розроблено алгоритм комплексного показника якості виготовлення роз'ємних конструкцій паперово-білової продукції, чим сформульовано вимоги до продукції та потреби або очікування користувачів.

\section{Список використаної літератури}

1. Хмілярчук О. І. Аналіз конструкцій видань зі змінними елементами блоку та сфери їх використання / О.І.Хмілярчук, М. О. Клішина // Технологія і техніка друкарства. 2018. № 3(61). C. 38-46. DOI: http://doi.org/10.20535/ 2077-7264.3(61).2018.155197.

2. Хмілярчук О. І. Технологічні особливості виготовлення видань зі змінними елементами блоку / О. І. Хмілярчук, М. О. Клішина // Технологія і техніка друкарства. 2018. № 4(62). C. 39-47. DOI: http://doi.org/10.20535/20777264.4(62).2018.158009.

3. Хмілярчук О. І. Оцінка якості гарячого тиснення фольгою на шкірі та замінниках шкіри / О. І. Хмілярчук, К. О. Чепурна, Ю. В. Екгардт // Технологія і техніка друкарства. 2012. № 3(37). C. 87-96. DOI: http://doi.org/10.20535/2077-7264.3(37).2012.32403.

4. Хмілярчук О. І. Роз'ємні конструкції паперово-білової продукції: сфера поширення, види, класифікація / О. І. Хмілярчук, М.О.Клішина // Технологія і техніка друкарства. 2020. № 4(70). C. 15-24. DOI: http://doi.org/10.20535/ 2077-7264.4(70).2020.225645.

5. СОУ 18.1-02477019-08:2017. Вироби друковані канцелярські паперові чи картонні. Загальні технічні вимоги (зі зміною № 1). На заміну СОУ 22.2-02477019-08:2007; чинний від 2013.08.01.

6. СОУ 18.1-02477019-09:2015. Видання. Видавниче оформлення і поліграфічне виконання. Показники якості. На заміну СОУ 22.2-02477019-09:2007.

7. Булах Т. Система критеріїв оцінювання якості книжкової продукції / Т. Булах // Вісник Книжкової палати, 2013. № 8. С. 3-7.

8. Гавенко С. Ф. Оцінка якості поліграфічної продукції / С. Ф. Гавенко, О. В. Мельников. За ред. д-ра техн. наук проф. Е. Т. Лазаренка. Львів: Афіша, 2000. $120 \mathrm{c}$. 
9. С. Ф. Гавенко. Інтегральний прогноз якості книжкових видань / С. Ф. Гавенко, В. М. Сеньківський, Н. Є. Сеньківська // Інформаційні технології і автоматизація поліграфічного виробництва. 2011. № 2. С. 144-148.

10. Пашуля П. Л. Стандартизація, метрологія, відповідність, якість у поліграфії: підруч. / П. Л. Пашуля. Львів: УАД, 2011. 408 с.

11. Андрієвська Л. Оцінка якості паперової продукції санітарно-гігієнічного призначення / Л. Андрієвська, Т. Глушкова, С. Пилипенко // Товари і ринки. 2012. № 1. С. 164-170. Режим доступу: https://nbuv.gov.ua/UJRN/ tovary 2012123.

\section{References}

1. Khmiliarchuk, O. I. \& Klishyna, M. O. (2018). Analiz konstruktsii vydan zi zminnymy elementamy bloku ta sfery yikh vykorystannia [Analysis of Designing of Books and Others Editions, Which Have Variable Elements in its Structure, and Their Areas of Use]. Tekhnolohiia i tekhnika drukarstva, 3(61), 38-46. DOI: http://doi.org/10.20535/2077-7264.3(61).2018.155197 [in Ukrainian].

2. Khmiliarchuk, O. I. \& Klishyna, M. O. (2018). Tekhnolohichni osoblyvosti vyhotovlennia vydan zi zminnymy elementamy bloku [Technological Features Production of Editions, Which Have Variable Elements in Structure]. Tekhnolohiia i tekhnika drukarstva, 4(62), 39-47. DOI: http://doi.org/ 10.20535/2077-7264.4(62).2018.158009 [in Ukrainian].

3. Khmiliarchuk, O. I. \& Chepurna, K. O. \& Ekhardt, Yu. V. (2012). Otsinka yakosti hariachoho tysnennia folhoiu na shkiri ta zaminnykakh shkiry [Assessment of quality of hot stamping by foil on the leather and the leather substitutes]. Tekhnolohiia i tekhnika drukarstva, 3(37), 87-96. DOI: http://doi.org/ 10.20535/2077-7264.3(37).2012.32403 [in Ukrainian].

4. Khmiliarchuk, O. I. \& Klishyna, M. O. (2020). Roz'iemni konstruktsii paperovo-bilovoi produktsii: cfera poshyrennia, vydy, klasyfikatsiia [Dismountable Structures of Paper-White' Products: Scope of Application, Types, Classi-fication]. Tekhnolohiia i tekhnika drukarstva, 4(70), 15-24. DOI: http://doi.org/ 10.20535/2077-7264.4(70).2020.225645 [in Ukrainian].

5. Vyroby drukovani kantseliarski paperovi chy kartonni. Zahalni tekhnichni vymohy (zi zminoiu № 1). Na zaminu SOU 22.2-02477019-08:2007 [Printed Stationery, Paper or Cardboard. General Technical Requirements]: SOU 18.102477019-08:2017: Chynnyi vid 2013.08.01 [in Ukrainian].

6. Vydannia. Vydavnyche oformlennia i polihrafichne vykonannia. Pokaznyky yakosti [Editions. Publishing Design and Printing. Quality Indicators]: SOU 18.102477019-09:2015. Na zaminu SOU 22.2-02477019-09:2007 [in Ukrainian].

7. Bulakh, T. (2013). Systema kryteriiv otsiniuvannia yakosti knyzhkovoi produktsii [System of Criteria for Evaluating the Quality of Book Products]. Visnyk Knyzhkovoi palaty, 8, 3-7 [in Ukrainian].

8. Havenko, S. F. \& Melnykov, O. V. (2000). Otsinka yakosti polihrafichnoi produktsii [Evaluation of the Quality of Printing Products]. Lviv: Afisha, 120 p. [in Ukrainian].

9. Havenko, S. F. \& Senkivskyi, V. M. \& Senkivska, N. Ye. (2011). Intehralnyi prohnoz yakosti knyzhkovykh vydan [Integrated Forecast of Quality of Book Editions]. Informatsiini tekhnolohii i avtomatyzatsiia polihrafichnoho vyrobnytstva, 2, 144-148 [in Ukrainian]. 
10. Pashulia, P. L. (2011). Standartyzatsiia, metrolohiia, vidpovidnist, yakist u polihrafii [Standardization, Metrology, Compliance, Quality in Printing]. Lviv: UAD, 408 p. [in Ukrainian].

11. Andriievska, L. \& Hlushkova, T. \& Pylypenko, S. (2012). Otsinka yakosti paperovoi produktsii sanitarno-hihiienichnoho pryznachennia [Quality Assessment of Paper Products for Sanitary and Hygienic Purposes]. Tovary $i$ rynky, 1, 164-170. Retrieved from https://nbuv.gov.ua/UJRN/tovary_2012_ 123 [in Ukrainian].

In the article the complex quality coefficient of editions with have dismountable construction of paper-white production in their structure was investigated; the significance of the influence of factors on the quality of the production of these products was investigated by method of expert assessments and developed Ishikawa diagram; an quality' control algorithm of the production of detachable structures of paper-white products was formed.

Keywords: quality assessment; design of paper-white products; variable elements of publications; type of binding notebooks; detachable editions; post-printing operations; technological features of manufacturing.

Надійшла до редакції 27.02.21 